\title{
メンタルモデルにもとづく運転者の進路推論に 関する研究
}

\author{
野村哲郎 $1 \cdot$ 外井哲志 ${ }^{2} \cdot$ 清田 勝 3 \\ ${ }^{1}$ 正会員 株式会社コルバック 技術開発室（テ110-0016 東京都台東区台東4-8-7） \\ ${ }^{2}$ 正会員 工博 九州大学大学院助教授 工学研究院環境都市部門（下812-8581 福岡県福岡市東区箱崎6- \\ 10-1) \\ ${ }^{3}$ 正会員 工博 佐賀大学教授 理工学部都市工学科（广840-8502 佐賀県佐賀市本庄町1）
}

\begin{abstract}
本研究では, 案内情報が不十分な状況下で, 運転者が分岐点間の認知的距離と走行経路の形状に関する 記憶によって進路を推論する機構を認知科学におけるメンタルモデルの考えにもとづいて考察し，この機 構を組み込んだ運転者行動モデルを構築した. 本研究における進路推論モデルでは, 走行前の既知情報お よび走行中の獲得情報の特性, また案内標識の有無などを進路決定の条件として, 数理モデルによる各種 の推論を定式化している. さらに, 従来の推論を考慮しない場合との比較を行い, 進路推論モデル導入に よる迷走量の変化を分析した.
\end{abstract}

Key Words : cognitive map, course choice, inference, mental model, road sign, traffic information

\section{1. まえがき}

道路案内標識の目的は, 地理不案内の運転者が迷走す ることなく，また不安感なく目的地に到達できるように 彼らを誘導することである. したがって, 案内誘導の検 討内容の枢要は運転者の迷走を最小限に抑えるように, 道路網上の標識設置位置と表示内容を決定することであ ると考えられる.

こうした観点からの道路案内標識に関する研究として は, これまでに, 道路案内標識の表示内容の一貫性を確 保するためのルールの確立を目的とした連続網の理論1), 交差点流入部に案内標識を設置することの案内誘導効果 の評価方法 ${ }^{2)}$, 道路案内標識による目的地一の到達の容 易性の定量的評価モデル3),4)などがあった.

この他, 著者の一人である外井 ${ }^{5}$ は, 地名案内に限定 して，情報エントロピーを用いた迷走度あるいは標識設 置数を最小化する最適化手法を提案し, 道路網における 案内標識の最適配置の検討を可能にした. これに引き続 き，著者ら るために, 各ODの迷走度を等しくするという目的関数 を導入し, 路線番号のみを用いた案内方式に関して外井 の方法 ${ }^{5}$ を発展させ, 路線案内を上位問題, 地名案内を 下位問題とした数理モデルによる最適化手法を開発し $\star^{7}$.

ところで, これらの研究は, いずれも運転者の迷走 を防止することを目的とするに止まり，迷走状態にある 運転者に対する配慮が欠けていた，案内誘導システムは, 迷走状態に対応できる機能が組み込まれてはじめて, そ の完備性が確保できると考えられる．そこで著者ら ${ }^{8}$ は， 迷走した運転者を予定経路一復帰させる, あるいは, 代 替経路へ導く『経路復元誘導機能』を発案し, 同機能を 組み込んだ案内誘導システムの構築法を提案した.

このモデルでは，既知情報に適った案内がなされた 場合のみ, 運転者は進路を決定できるものと仮定した.

しかし，実際には，すべてのODに対して運転者の既知 情報に適った完全な経路誘導を行うことは不可能であり， 一般に運転者は十分な情報を与えられず，走行の記憶や 推論にもとづいた感覚的な判断によって進路を選択せざ るを得ないことが多い.このような理由から, 上記の仮 定は必ずしも現実的ではないと考えられる.

本来望ましい案内誘導システムは, 迷走者を含めた 運転者の進路選択の推論に対しても十分に対応できるも のでなくてはならず, また一方で, 運転者のこうした推 論能力に依拠できれば，より合理的で経済的な案内誘導 システムをめざすことが可能になる.この点に関して, 進路選択時の運転者の推論を含んだ意思決定に関する研 
究は，ほとんど行われていないのが実情であり，経路選 択行動のモデル化への認知科学的取り組みの必要性を示 唆した研究皃があるのみである.

本研究では，このような観点から，従来の評価モデ ル に組み込むべき推論機能のモデル化に関する考察を 行ったものである.このために, 認知科学におけるメン タルモデルの考え方にもとづいて，運転者の行動をより 正確に表現するために，経路走行に関する情報と進路推 論の関係を考察した後, 進路推論の演算を組み込んだ経 路走行モデルを構築した. さらに, 走行距離および到達 迷走度8) などを評価指標として，推論を考慮しない場 合との比較にもとづいて, 進路推論モデル導入による基 礎的な効果を検証したものである.

\section{2. 経路走行におけるメンタルモデル}

本研究では，運転者は経路に関する情報と推論にも とづいて進路決定を行うと考える.このときの情報とし ては, 出発前に運転者が淮備した既知情報と, 出発後に 案内板やランドマークなどから得る獲得情報の 2 種類の 情報が考えられる.

既知情報は，予定経路という形で統合的に把握され， 運転者は，これにもとづいて認知地図（頭の中の地図） を形成すると考えられる，獲得情報は，文字・記号・ラ ンドマークなどの認知を通して, 情報として取り入れら れる．なお，標識による案内情報も獲得情報の一部であ る.

運転者は，既知情報にもとづいて獲得情報の内容を 吟味し， 2 種類の情報を比較することによって，自分の 現在位置や走行状況（迷走状況）を確認・判断しながら 走行する. また，迷走状態に陥ったと判断した場合には， 直前までの走行経路に関する記憶と案内板などから得た 獲得情報を用いて推論し, 予定経路への復帰を図る.

認知科学では, 外界に実在する事物の代わりとして 心内に構成され，心的な操作の対象となるものを『メン タルモデル(10)』と呼んでいる。これと類似の表現として， 『表象』という概念がある. 表象は，狭義には『視覚的 イメージ』であり，広義にはある対象に対寸る知識を意 味するとされている ${ }^{10)}$.

メンタルモデルは, 表象と比較して, 思考の道具として 心内で操作し推論に使われるという意味合いが強い。こ の点から本研究では, メンタルモデルの概念を用いるこ ととし, 経路走行中の運転者による上述の一連の情報処 理システムを「経路走行のメンタルモデル」（以下，単 に「メンタルモデル」）と称することとした．また，こ のモデルの構成要素として認知地図がある. 広義の認知 地図には，場所の位置に関する情報のみならず，その属

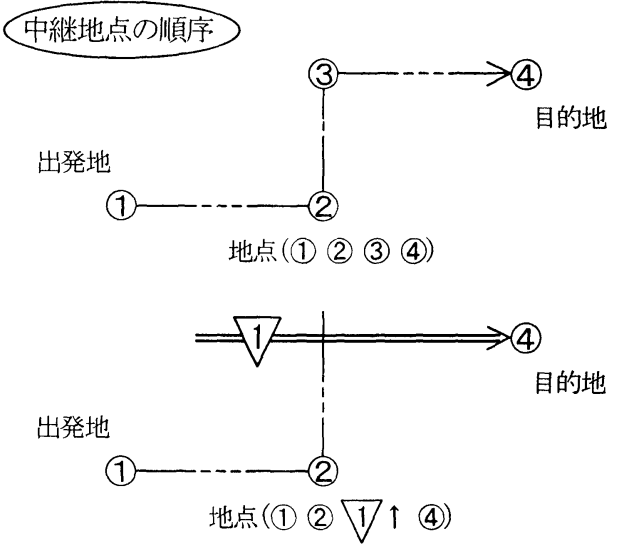

図-1 地点情報

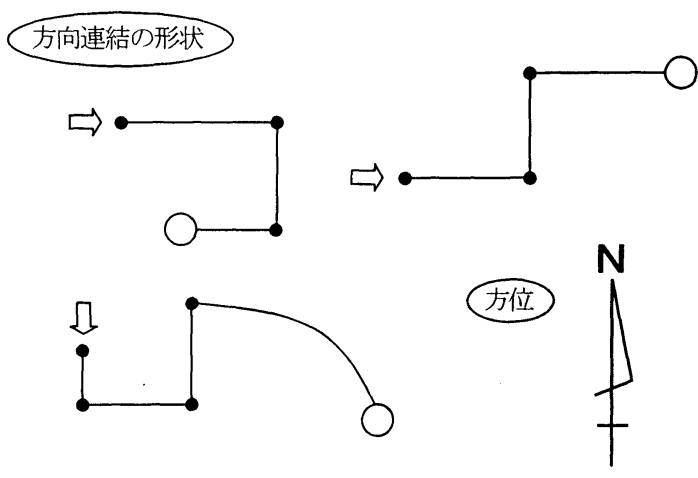

図-2 方向情報

性や情緒的意味の情報も含まれることになるが，本研究 で対象とするのは，場所の位置に関わる空間的性質であ る情報の構造化のみとする.

ところで,メンタルモデル上の推論を観測や実験によ って明らかにすることは容易ではない，そこで，本研究 では, 問題解決における認知プロセス研究の方法論とし て，機能を再現すればよいという立場から，記号による 処理を中心とした「情報処理的アプローチ(1),12)」を試み ることとした.

ここで, 本研究のメンタルモデルにおいて重要な役割 をもつ情報, 推論, 迷走の 3 要素について, 以下に述べ る.

\section{（1）情報}

\section{a）予定経路と既知情報}

これから走行しようとする経路を『予定経路』という。 また，予定経路に関する中継地名や路線名，経路の形状， 中継地点間や経路全体の距離や時間などに関する情報 （知識）を『既知情報(2)77,8)』と定義する．既知情報には， 
『地点情報』，『方向情報』，『結合情報』および『距 離情報』がある.

\section{b）地点情報}

地点情報とは，図-1 に示すように，ある中継地点か ら次の目標となる中継地点または方面への中継順序，つ まり中継となる地点または方面の通過順序とその数など である.この他に, 中継地点の大きさや特徵なども地点 情報に含まれる，運転者は，主に走行前に，多くの組み 合わせの中から予定経路を走行する上で最低限必要な要 素を記憶する.

\section{c）方向情報}

方向情報とは，図-2 に示すように，経路の形状，リ ンクの形状，ターニングポイントでの次の方面への角度， 方位などである．運転者は，主に走行前における予定経 路の静的形態（屈折などの形状とその出現順序の組み合 わせ）を情報として記憶する.

ただし，複雑な形状の記憶は困難であり，認知形状 は，おおまかな形となる，すなわち，方向情報には『認

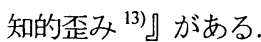

\section{d）結合情報}

結合情報とは，地点情報に関する集合の要素と方向 情報に関する集合の要素とを対応させ組み合わせた合成 要素の順序集合である。一般に運転者は，地点情報と方 向情報を個別にではなく，結合情報として理解し記憶す るものと思われる．ただし，推論を行う場合には地点情 報，方向情報を個別に使用することもあり得ると考える．

\section{e）距離情報}

距離情報とは，中継地点間のリンク長または経路の 総リンク長である．その数值は，「幾何距離」または 「時間距離」を表す，なお，距離情報にも「認知的歪 み」がある。

\section{f）認知的経済性}

認知的歪みは，空間的情報が構造化される過程で生じ， その傾向としては, 道路網のレイアウト地形が概念的構 造化に対して基準線を与え，認知方向はその基準軸に合 わせるようなズレを生じる（回転ヒューリスティクス）。 また，手書き地図分析からの経験則としては，交差点が 実際には斜交していても，直角に描かれ，曲がりくねつ た道路は直線化される傾向にある（整列ヒューリスティ クス）とされている。このような空間的構造化は，運転 者が空間的構造の理解を容易にするために，情報の単純 化を行った結果であり，認知的経済性と呼ばれる ${ }^{(4)}$.

現実の道路網では，複雑な形状を呈しており，この認 知的経済性が働くため, 分岐点における方向転換時の角 度・方向および走行道路の曲線性などを原因として, 認 知的歪みは大きくなる.

\section{（2）推論}

運転者は，既知情報と獲得情報との比較によって， (1)予定経路を走行中であるかどうかを推論する（比較推 論）。しかし，(2)予定経路を走行中でない場合，または 情報が不十分で，比較推論では進路を決定できない場合 には，代替路（予定経路に復帰する経路）を推論する （代替推論）と考える.

\section{a）比較推論}

運転者は，出発前に想定した予定経路あるいは更新 された予定経路に関する既知情報と，走行中に獲得した 情報を比較し, 現在予定経路を走行中であるかどうかを 推論すると考えられる. これを『比較推論』と呼ぶこと にする，比較推論では，結合情報による比較，方向情報 による比較，地点情報による比較および距離情報による 比較が行われる.

メンタルモデルにおける『比較』は，既知情報をべー スとして，獲得情報を対象とした「比較推論」によって 行われる. 比較推論が困難なとき，またはその信頼性が 低いときには，以下に述べる『代替推論』が行われる.

\section{b）代替推論}

既知情報である中継地点名の案内がない場合でも， 記憶していた走行形状や間欠的な地点名の順序集合と比 較することにより，現在の位置を推定することができる，

また，既知情報の方面と違う方向に予定中継地点の 案内があったり，予定よりも長い距離を走行しても目的 地点に到達しない場合など，予定経路から外れたと思わ れるとき，さらに道路の混雑状況や通行止めなどにより， 走行途中で経路を変更せざるを得ないときには，「代替 推論」によって目的地点への変更経路を推論する.

つまり,「代替推論」とは, 中継地点相互のより短い 経路での連続性，または予定中継地点を通らない非連続 性, 各中継地点の逆転関係，接続関係などを注目の対象 として, 各交差点流入部で次の進行方向を選択した場合, 目標地点に到る経路にどういう結果をもたらすか，予定 経路に復帰するにはどちらの進行方向を選ぶべきかなど を考察し，予定経路とは異なる経路の検討を行うことを 意味する.

大多数の運転者は, 走行距離や屈折回数などの記憶 にもとづいた感鸴的な方角の同定によって進路を決定す ると考えられるが，状沉によっては，論理的に推論が可 能な場合もある.

そこで本研究では, 代替推論において一種の論理演算 またはそれと同等の効果をもつ推論が行われるものと考 え, 後述寸る『方向演算』(主として方位・方角と屈折 履歴を用いる代数演算）を導入することとした.

なお，推論は，ヒューリスティクス (“heuristics” 発 見的思考）であり，したがって，必ずしも最適な判断と は限らない.すなわち，「人間は不完全な情報をもとに 
して推論する能力を持っており, 不完全な情報からの推 論は, 後の情報の増加により結論が翻ることがあ

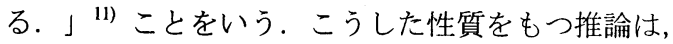
『非単調推論』と呼ばれている，本研究では，運転者の 推論は非単調な性質をもつものと考える.

\section{（3）迷走}

本研究では, 予定経路からはずれて走行し, 代替路を 発見することができなくなった状態での走行を『迷走』 と定義する. この状態では, 進路の決定に論理的根拠は 失われ，進路は感覚的に選択される.

しかし，迷走の途中で獲得した情報が既知情報と関 連をもつ場合, 推論の力を借りて予定経路への復帰路 （代替路）を発見できる場合や，迷走しながら偶然に中 継地・目的地に到着できることもある。

本研究においては, 走行中の運転者の迷走状態を検知 し, 迷走状態にある場合には, 進行方向はランダムに決 定されるものとしている.

\section{3. メンタルモデルにおける情報と推論の数学的 表現}

\section{（1） 既知情報の表現}

既知情報の内容は，地点情報に関する順序集合にもと づく出発地および目的地, そして経由する地名・路線番 号とその順序であり, 属性として方向情報の順序集合に もとづく交差点流入部での直進・右折・左折など方向に 関する情報，そして中継地点間または路線までの各リン ク長に関する情報を持つものとする.

一般的に，これらのうちで，案内に対して直接対応す る既知情報は, 案内方向別の地名または路線名 (主に番 号)であり，案内に対して直接には対応しない既知情報 は, 中継地点間または路線までの距離などである.

なお，運転者は，経路履歴のすべてを記憶しているの ではなく, 予定経路に関して運転者が必要と思う最小限 の中継地点や方向などを出発前に既知情報として記憶し， その記憶は変化しないとする．よって，それらに対する 忘却などは対象としない。

\section{a）案内情報に対して直接対応する既知情報の表現}

案内に対して直接対応する既知情報は, 経由地名・路 線名および目的地，そしてそれらの方向であり，以下の ように表現できる.

地点情報に関する順序集合については,

$$
\operatorname{via}\left(\cdots v_{i} \cdots\right)
$$

方向情報に関する順序集合については,

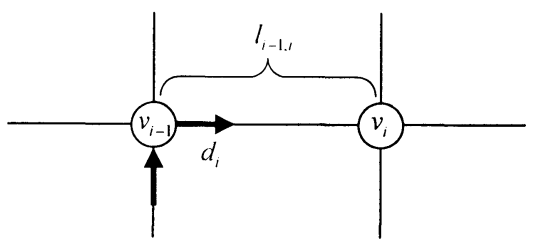

図-3 音号要素の関係

$$
\operatorname{direct}\left(\cdots d_{i} \cdots\right)
$$

地点と方向の結合情報に関する順序集合については,

$$
\begin{gathered}
\operatorname{concat}\left(\cdots \quad v_{i} \cdot d_{i} \cdots\right) \\
\equiv \operatorname{via}\left(\cdots v_{i} \cdots\right) \operatorname{direct}\left(\cdots d_{i} \cdots\right) \\
i=1,2, \cdots, n
\end{gathered}
$$

と表すことにする.

ここに, via $(\cdot)$ は $v_{i}$ の順序集合であり, $\operatorname{direct}(\cdot)$ は $d_{i}$ の順序集合である. また, concat(-)は, direct(-)とvia (·) を対応させて組み合わせた情報 $v_{i} \cdot d_{i}$ の順序集合であ り，○は，その代数演算子である.

なお，式(1)（3)における記号要素の関係を図-3に示 す， $v_{i}$ は i 番目の中継地名または路線名であり， $d_{i}$ は流 入部で進むべき方向（直進，右折または左折など）, $v_{i} \cdot d_{i}$ は $d_{i}$ の方向に進めば $v_{i}$ に到ることを意味する結合情報で ある.

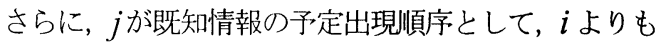
後の順序を表すとすると, $j$ に関する情報が優先される. すなわち，式(1)，(3)が，

$$
\begin{gathered}
\operatorname{via}\left(\cdots v_{i} \cdots v_{j} \cdots\right) \\
\text { concat }\left(\cdots v_{i} \cdot d_{i} \cdots v_{j} \cdot d_{j} \cdots\right)
\end{gathered}
$$

のとき，

$$
\begin{gathered}
v_{i} \prec v_{j} \\
v_{i} \cdot d_{i} \prec v_{j} . d_{j}
\end{gathered}
$$

という性質を持つものとする。ここに，〈は，左辺と右 辺が同時に案内された場合には, 後の項である右辺を優 先するという比較演算子とする，なお，方向情報（式 (2)）に関しては, これは成り立たない.

\section{b）案内情報に直接対応しない既知情報の表現}

案内に対して直接には対応しない既知情報として, 中継地点（または路線）間の距離やその所要時間が考え られるが, 本検討では距離を対象とし，その順序集合と しての表現を，

$$
\begin{gathered}
\operatorname{length}\left(\cdots l_{i-1, i} \cdots\right) \\
i=1,2, \cdots, n
\end{gathered}
$$



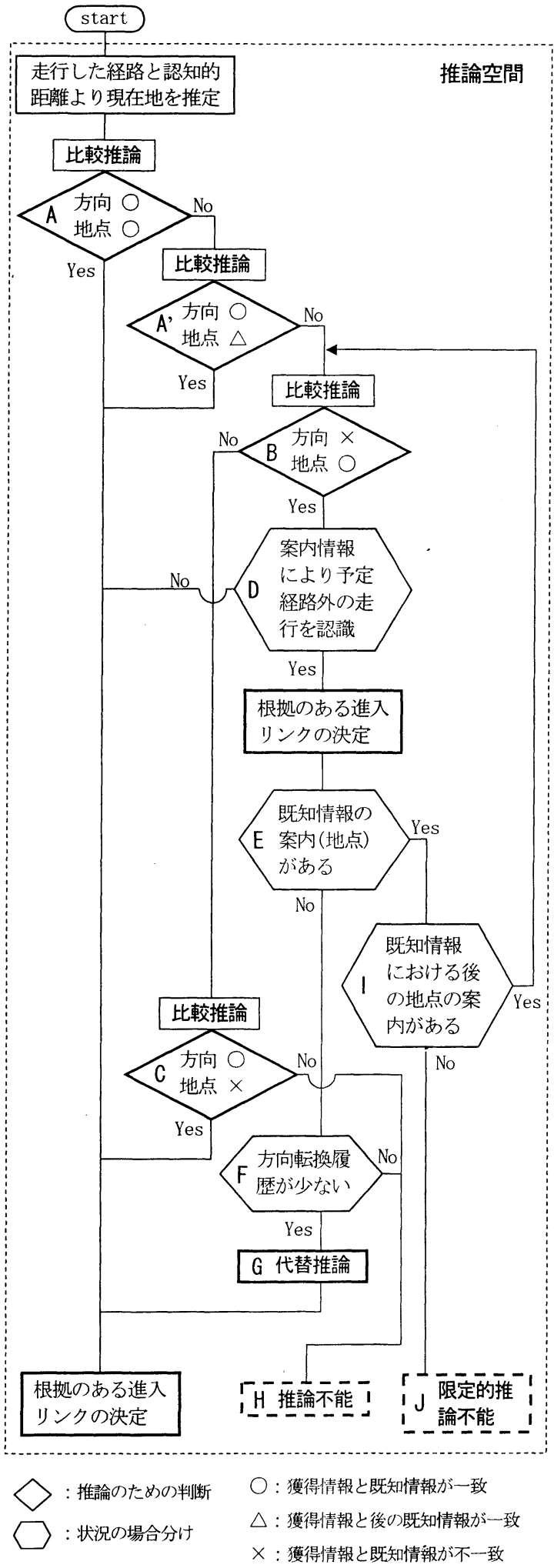

図-4 推論のフロー図
とする.

ここに, $i-1=0$ は出発地, $i=n$ は目的地を表す. また, $l_{i-1, i}$ は中継地点（または路線）間の認知的距離と する. よって, $l_{i-1, i}$ は真の距離ではなく, 認知的な歪み をもつ.

なお，認知的歪みは，距離情報だけではなく中継地点 間の方向情報も考えられるが，本研究では距離情報の認 知的歪みのみを対象とし，方向情報に関する認知的歪み は対象外とする。

\section{（2）運転者の進路選択基準}

ここで, 情報の充足状況による運転者の進路推論の流 れについて考察する. そのための推論フローを図-4に 示す.

\section{a）案内が十分な場合}

案内が十分な場合とは，既知情報の地点情報 $v_{i}$ と方向 情報 $d_{i}$ が地点 $v_{i-1}$ の流入部において過不足なく連続して 案内されるときをいう。つまり，走行中に獲得した結合 情報が既知情報の結合情報の部分順序集合になる場合で ある.このとき, 運転者は, 案内の指示どおりに進路を 選択すればよいことになる.これは，推論の流れを表し た図-4の「A (Yes) : 結合情報の部分集合を満足」に該 当する.

\section{b）案内が不十分な場合}

運転者は，走行中に獲得した情報の集合と既知情報 に関する順序集合が部分的に一致したときには, 次の場 合のように，案内がなくても推論によって進路を決定で きることがある.

第 1 には，既知情報における中継地点名が飛び飛び に案内された場合があげられる.

これは走行中の運転者が，予定経路上では先に現れ

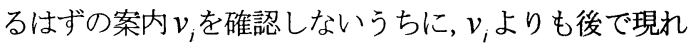
るはずの $v_{j}$ の案内に遭遇する場合である.

このケースに関しては, $v_{j}(j>i)$ の案内が $v_{i}$ の案内 と同等の役割を果たしていると考えることができるので， 結合情報の代理部分集合を満たしているといえる.

このとき, 運転者が $v_{i-1}$ に到達したことを認識済みで あり，その案内方向が $d$ であれば，そのリンクに進入す る.（図-4の A' Yes：結合情報の代理部分集合を満足） なお，方向情報の集合に関しては，要素が間久した集 合は，あり得ないものとする.

第 2 には，既知情報と異なる方向ではあっても $v_{i}$ の 案内情報が表示されていれば, 結局は $v_{i}$ が案内されてい る方向のリンクを選択することとなる（図-4 のB Yes : 地点情報の部分集合を満足).

第 3 には，運転者が予定経路を走行しようとすると き, 認知的距離に見合う位置に兓知情報の地点情報案内 が無い場合が考えられる.この場合は，運転者は地点情 


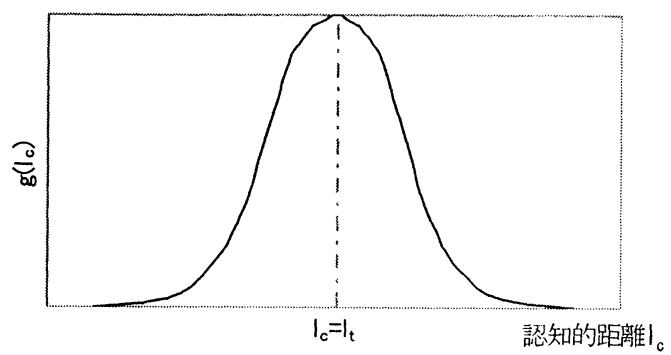

図-5 真の距離に対する認知的距離の分布

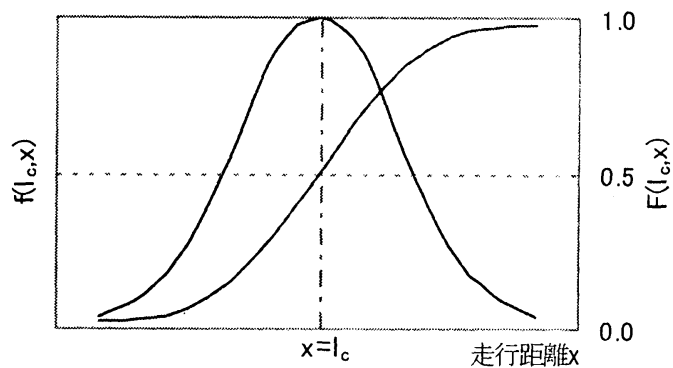

図-6 方向転換同定の確率分布

報の順序と過去に案内された情報との関係を分析するこ とにより, 現在の位置を推定し, 進入すべきリンクの推 論を行うこととなる.

これは，図-4の「C (Yes)」に該当し，運転者は，方 向情報と認知的距離をよりどころとして進入すべきリン クを推論することとなる．運転者が，既知情報にもとづ いて「距離的にはそろそろ右(左)折すべき場所に近づい た」と考えたとき，直近の分岐点で右(左)折するか，も う少し先まで直進するか迷うであろう。また，運転者が

「もしかすると曲がるべき分岐点を通り過ぎたかもしれ ない」と考えたときには，その分岐点からあまり離れな いうちに右(左)折しようとするであろう。いずれの場合 にも，現在地が予定経路上の右(左)折すべき分岐点に近 ければ，運転者が現在地で右(左)折する確率が高くなり， 離れるにしたがって，その確率は低下すると考えられる。 本研究では，こうした運転者の意志決定の近似則を 以下のように確率的に捉えることを試みる.

すなわち, 運転者は, 中継地点 (目標分岐点) $v_{i-1}$ と $v_{i}$ の間の距離 $l_{i-1, i}$ を認知的距離として把握しており, $v_{i-1}$ を通過してから，この距離を走行した位置に $v_{i}$ があ ると期待しているものとする.

しかし, $l_{i-1, i}$ は認知的距離であり, 各運転者による距 離認知の歪み（誤差）を含んでいるから，図-5 のよう に, 認知的距離 $l_{c}$ は真の距離 $l$,のまわりに分布する確率
変数であると考えることができる.

したがって，ある運忶者が認知的距離 $l_{c}$ を走行した としても，その位置に目的分岐点が存在するとは限らず， このときには，運転者が本来選ぶべき分岐点を正確に選 ぶことが困難になる．したがって，目標分岐点の前後に 類似の分岐点があれば，䛊ってそれらを目標分岐点に同 定してしまう場合も考えられる.

このように考えると, 認知的距離 $l_{c}$ に近い距離を走 行した位置に分岐点があれば，その分岐点を目標分岐点 であると同定する確率は高まるであろう。よって, 走行 距離 $x$ と認知的距離 $l$ ，に依存した図-6 のような確率分 布の存在を仮定することができる.

ところで，運転者は予定経路を走行しているつもり でも，実際には予定経路资晩脱している場合（例えば， 後述図-7）に，予想外の方向に表示された $v_{i}$ の案内によ って，自分が予定以外り経路を現在走行中であることを 知ることがある（図-40D Yes）。

このとき， $v_{i}$ の示されている方向へ進入し，そのリン クには既知情報に関する案内がなく（図-4 のE No），そ れまでの方向転換数が少ない場合（図-4 のF Yes）には， 走行経路の履歴にもと一゙き，予定経路へ復帰するための 代替推論（図-4のG）价可能となる。しかし，それまで の方向転換数が多い場命（図-4 の F No）には推論不能

（図-4のH）となる.

ところが， $v_{i}$ の示されている方向一進入し，そのリン クには既知情報に関する案内があり，それが $v_{i}$ 後の既知 情報 $v$,である場合（図-4のI Yes）には，地点情報に関 する比較推論（図-4のB）に戻り，既に通過したと思わ れる地点または路線名り案内しかない場合（図-4の। №）には，それが示されている方向以外の方向をランダ ムに選択（図-4の J : 煺定的推論不能）する.

\section{（3）推論の表現}

情報の内容を地名または路線名（記号 $v$ ) と方向(記 号 $d$ )および距離(記号 l)の 3 種類に限定し, 既知情報 と獲得情報の記号表現について説明する.

走行前の既知情報における目的地までの地点情報の 順序集合は,

$$
v^{o} \equiv \operatorname{via}\left\{v_{1}^{o}, v_{2}^{o}, \cdots, v_{i}^{o}, \cdots, v_{q}^{o}\right\}
$$

方向情報の順序集合は,

$$
\mathrm{d}^{\circ} \equiv \operatorname{direct}\left\{d_{1}^{\prime \prime}, d_{2}^{\prime \prime}, \cdots, d_{i}^{\prime \prime}, \cdots, d_{q}^{o}\right\}
$$

とする.

記号 “o”は，既知情此わ内容であることを表し，要 素の右下添字は, 既知惟浻の予定出現順序を現す，qは 既知情報の番号の最大值である.よって, $v_{q}^{o}$ は目的地で あり， $d_{q}^{0}$ は目的地に到る最終の進入方向となる。

結合情報の順序集合は, 


$$
v^{o} \cdot d^{o} \equiv \operatorname{concat}\left\{\begin{array}{l}
v_{1}^{o} \cdot d_{1}^{o}, v_{2}^{o} \cdot d_{2}^{o}, \cdots \\
v_{1}^{o} \cdot d_{1}^{o}, \cdots, v_{q}^{o} \cdot d_{q}^{o}
\end{array}\right\}
$$

とする.

現走行時点までの地点情報の順序集合は，

$$
\mathrm{v}_{\mathrm{r}}^{\mathrm{p}} \equiv \operatorname{via}\left\{v_{1}^{p}, v_{2}^{p}, \cdots, v_{i}^{p}, \cdots, v_{r}^{p}\right\}
$$

とし, $\mathbf{v}_{\mathrm{r}}^{\mathrm{p}}$ の要素は, 集合 $\mathbf{v}_{\mathrm{r}}^{\mathrm{o}}$ に属する.

方向情報の順序集合は,

$$
\mathbf{d}_{\mathrm{r}}^{\mathrm{p}} \equiv \operatorname{direct}\left\{d_{1}^{p}, d_{2}^{p}, \cdots, d_{i}^{p}, \cdots, d_{r}^{p}\right\}
$$

とする.

ここに，記号 “p” は，現走行時点の獲得情報の内容 であることを表し，要素の右下添字は，その獲得順序を 現す．また, $r$ は既知情報と一致した現走行時点までの 最新獲得情報の番号であり, $\mathrm{v}_{\mathrm{r}}^{\mathrm{p}}$ および $\mathrm{d}_{\mathrm{r}}^{\mathrm{p}}$ の要素数でも ある

したがって， $d_{r}^{p}$ は，今まさに，交差点流入部におい て選択リンクに進入した場合の方向を表し， $v_{r}^{r}$ は，次の 中継地名または路線名を表す。

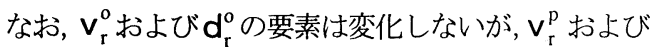
$\mathrm{d}_{\mathrm{r}}^{\mathrm{p}}$ の要素は走行にともなって増加していく.

現走行時点までの結合情報の順序集合は,

$$
v_{\mathrm{r}}^{\mathrm{p}} \cdot \mathrm{d}_{\mathrm{r}}^{\mathrm{p}} \equiv \text { concat }\left\{\begin{array}{l}
v_{1}^{p} \cdot d_{1}^{p}, v_{2}^{p} \cdot d_{2}^{p}, \cdots \\
v_{i}^{p} \cdot d_{i}^{p}, \cdots, v_{r}^{p} \cdot d_{r}^{p}
\end{array}\right\}
$$

とする.

したがって，情報集合 $d_{r}^{p}, d^{0}, v_{r}^{p}, v^{0}$ に対寸る進入リ ンク方向 $g_{r}^{p}$ は，以下 $\left.\mathrm{a}\right) \sim \mathrm{g}$ )のように表現することがで きる.

a）結合情報がー致した場合の推論

結合情報に関する案内情報集合 $v_{\mathrm{r}}^{\mathrm{p}}$. $d_{\mathrm{r}}^{\mathrm{p}}$ が既知情報 $v^{0} \cdot d^{0}$ の部分順序集合となっているとき，つまり，既知情報の 予定中継地点と思われる地点 $v_{r-1}^{o} に$ 到達したところに標 識が設置されており，「 $d_{r}^{o}$ 方向のリンクに進入すれば $v_{r}^{o}$ に到る」という案内がある場合には, 進入方向 $g_{r}^{p}$ は式 (15)で表される.これは，図-4のA（Yes）に該当寸る.

$$
\begin{gathered}
g_{r}^{p}=d_{r}^{p} \\
\left(\begin{array}{l}
v_{r}^{p}=v_{r}^{o}, d_{r}^{p}=d_{r}^{o}, \\
v_{r}^{p} \cdot d_{r}^{p} \in v^{o} \cdot d^{o}
\end{array}\right)
\end{gathered}
$$

\section{b）代理結合情報が一致した場合の推論}

既知情報の予定中継地点と思われる地点 $v_{r-1}^{o}$ に到達し, $\left\lceil d_{r}^{o}\right.$ 方向のリンクに進入すれば $v_{r+r}^{o}$ に到る」という案 内がある場合には，進入方向 $g_{r}^{p}$ は式(16)で表される.

ここに, $v_{r+\gamma}^{o}$ は, $v_{r+\gamma}^{o} \succ v_{r}^{o}$ の関係にあり, $v_{r}^{o}$ の後の既 知地点情報である。

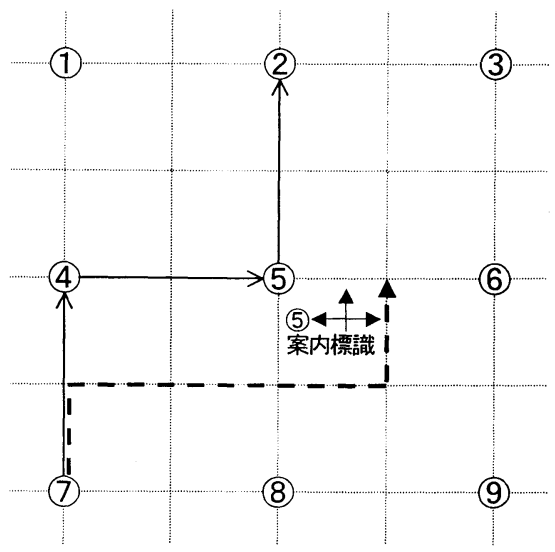

図-7 方向則の説明図

$$
\begin{gathered}
g_{r}^{p}=d_{r}^{p} \\
\left(\begin{array}{l}
v_{r}^{p}=v_{r+\gamma}^{o}, d_{r}^{p}=d_{r}^{o}, \\
\mathrm{v}_{\mathrm{r}-1}^{\mathrm{p}} \in \mathrm{v}^{\mathrm{o}}, \mathrm{d}_{\mathrm{r}}^{\mathrm{p}} \in \mathrm{d}^{\mathrm{o}}, \mathrm{v}_{\mathrm{r}-1}^{\mathrm{p}} \cdot \mathrm{d}_{\mathrm{r}-1}^{\mathrm{p}} \in \mathrm{v}^{\mathrm{o}} \cdot \mathrm{d}^{\mathrm{o}}
\end{array}\right)
\end{gathered}
$$

よって, 走行中の最新の案内内容は,

$$
v_{r}^{p} \cdot d_{r}^{p}=v_{r+\gamma}^{o} \cdot d_{r}^{o}
$$

となる.

このとき， $v_{r}^{o}$ のあとの地点情報である $v_{r+\gamma}^{o}$ を $v_{r}^{o}$ と見 な寸とすると, 式(17)の右辺を $v_{r}^{o}$. $d_{r}^{o}$ と推論できること となる．したがって，結合情報のレベルの案内情報集合 $v_{r}^{p}$. $d_{r}^{p}$ が既知情報 $v^{o} \cdot d^{o}$ \%代理部分順序集合となり，こ の場合は，図-4の $A^{\prime}$ (Yes) に該当する.

なお, $\gamma$ は

$$
r+1 \leq r+\gamma \leq q
$$

を満足する任意の数である.

c）地点情報が一致した場合の推論

走行中の中継地点の案内は既知情報の地点情報と一致 するが，その示された方向は既知情報の方向情報とは一 致しない場合，つまり走行中の地点情報 $\mathbf{v}_{\mathrm{r}}^{\mathrm{p}}$ は既知情報 の地点情報 $v^{0}$ の部分順序集合とはなるが，走行中の方 向情報 $\mathrm{d}_{\mathrm{r}}^{\mathrm{p}}$ は既知情報の方向情報 $\mathrm{d}^{\mathrm{o}}$ の部分順序集合とは ならない場合である.このとき運転者の進入方向 $g_{r}^{p}$ は, 地名または路線名である $v_{r}^{p}$ が示されている方向である $d_{r}^{p}$ となり，式(19)で表される.これは図-4のB (Yes）に該当する.

$$
\begin{gathered}
g_{r}^{p}=d_{r}^{p} \\
\left(\begin{array}{l}
v_{r}^{p}=v_{r}^{o}, \\
\mathbf{v}_{\mathrm{r}}^{\mathrm{p}} \in \mathrm{v}^{\mathrm{o}}, \mathrm{d}_{\mathrm{r}}^{\mathrm{p}} \notin \mathrm{d}^{\mathrm{o}}
\end{array}\right)
\end{gathered}
$$

d）方向情報が一致した場合の推論

有効な案内がなく，走行中の経路形状だけが既知情報 の方向情報で描く形状と一致寸るとき（例えば，図-7 
の太破線部 直進 $\rightarrow$ 右折 $\rightarrow$ 左折)，つまり走行中の方向情 報 $\mathrm{d}_{\mathrm{r}}^{\mathrm{p}}$ が既知情報の方向情報 $\mathrm{d}^{\mathrm{O}}$ の完全部分順序集合とな る場合には，進入方向 $g_{r}^{p}$ は式(20)で表される。これは 図-4のC (Yes) に該当する。

この場合，運転者は，式(8)に示寸中継地点間の距 離情報と走行距離 $x$ にもとづいて, 図- 6 に示寸確率 $F\left(l_{c}, x\right)$ に従って方向転換すべき次の中継地点を同定 することとなる. このとき, $d_{r}^{o}$ が選択される傕率を $P\left(d_{r}^{o}\right)$ とする.

$$
\begin{gathered}
g_{r}^{p}=d_{r}^{o} \\
\left(\begin{array}{l}
\mathbf{v}_{\mathrm{r}}^{\mathrm{p}} \notin \mathbf{v}^{\mathrm{o}}, \mathrm{d}_{\mathrm{r}}^{\mathrm{p}} \in \mathrm{d}^{\mathrm{o}}, \\
P\left(d_{r}^{o}\right)=F\left(l_{r}^{c}, x_{r}\right)
\end{array}\right)
\end{gathered}
$$

ここに, $l_{r}^{c}$ は当該区間 $r$ における認知的距㒛を表し, $x_{r}$ は実際の走行距離を表す。

\section{e）予定経路外走行を認識した場合の推論}

図-7 の例では，運転者は，案内情報がない状態で， 既知情報の方向情報と距離情報にしたがって太破線(予 定経路外)を走行中である.このとき, 案内標識によっ て予定経路(細実線)の中継地点である(5)の案内が出現す る. しかし，その方向が既知情報の方向と違うことから， 予定経路外を走行していることを認識し，(5)が案内され ている方向に進路をとる. つまり，予定経路を走行して いると思っていた運転者が，既知情報の地点情報 $v_{r}^{o}$ が 方向情報 $d_{r}^{o}$ とは異なる方向に案内されることにより， 予定経路外を走行していることに気付き，このとき第 1 段階の推論として, $v_{r}^{p}$ で示される中継点に向かって進路 を取ることになる。

次に第 2 段階目の推論に関しては, 進行方向 $g_{r+1}^{p}$ は, 条件の違いによって式(21)から式(24)に示寸推論值が与 えられる。

まず， $v_{r}^{o}$ と思われる地点に到達する直前に有効な案 内はないが，その地点から，さらに進むべき方向 $\theta$ を推 論する場合があり，式(21)で表される.

これは, 方向転換数の記憶の上限值 $R$ 以下での方向 情報履歷が反映された場合であり，図-4のD $\rightarrow E \rightarrow F$ を 満足した後，G に至る代替推論（方向演算を用いた推 論）に該当する.

式(22)は, 走行中の方向転換数 $r$ が記憶の上限値 $R$ を 超えたために状況的推論不能となる場合である。これは， 図-4 の $\mathrm{D} \rightarrow \mathrm{E} \rightarrow \mathrm{F} \rightarrow \mathrm{H}$ に該当する.

式(23)，(24) は, 式(21)，(22)とは図-4のE 以後が異 なり，既知情報の地点情報が案内される場合である.

式(23)は, $v_{r}^{o}$ と思われる地点に到達寸る直前に, 後で 現れるはずの $v_{r+\gamma}^{o}$ の案内がなされ，その指示にしたがう 場合である. これは，図-4のD $\rightarrow \mathrm{E} \rightarrow \mid \rightarrow B$ に該当する.

式(24)は, $v_{r}^{o}$ と思われる地点に到達寸る直前に, $v_{r}^{o}$ 以 前の地点である $v_{r-\gamma}^{o}$ の案内がなされ，その案内方向であ
る $d_{r+1}^{p}$ を避け，それ以外の方向をランダムに選択する場 合（限定的推論不能）である. これは，図-4のD $\rightarrow E \rightarrow I$ $\rightarrow$ Jに該当する.

$$
\begin{gathered}
g_{r}^{p}=d_{r}^{p}, g_{r+1}^{p}=\left\{\begin{array}{l}
\theta\left(v_{r+1}^{p} \notin \mathrm{v}^{\mathrm{o}}, r \leq R\right) \\
\forall d\left(v_{r+1}^{p} \notin \mathrm{v}^{\mathrm{o}}, r>R\right) \\
d_{r+1}^{p}\left(v_{r+1}^{p}=v_{r+\gamma}^{o}\right) \\
\overline{d_{r+1}^{p}}\left(v_{r+1}^{p}=v_{r-\gamma}^{o}, r>R\right)
\end{array}\right. \\
\left(\begin{array}{l}
v_{r}^{p} \in \mathrm{v}^{0}, \\
\mathrm{v}_{\mathrm{r}}^{\mathrm{p}} \in \mathrm{v}^{0} \text { or } \mathrm{d}_{\mathrm{r}-1}^{\mathrm{p}} \in \mathrm{d}^{\mathrm{o}}
\end{array}\right)
\end{gathered}
$$

ここに, $\theta$ は代替推論結果にもとづいたその進入すべ きリンクの方向を表す．また, $\forall d$ はとりうる進路方向 の中から任意の進路を選択することを， $\forall \overline{d_{r+1}^{p}}$ は， $d_{r+1}^{p}$ 以外の任意の進路を選択することを表す.

\section{f）推論不能}

推論不能状態は 2 種類あり，1つは式(22)で述べた.

もう1つの場合を以下に述べる.

式(25)は，走行中の地点情報，方向情報が両者とも既 知情報の部分順序集合とならない場合であり, 情報欠如 による論理的推論不能状恁となる. 運転者は, このとき ランダムウオークとなる. これは, 図-4 の $A \rightarrow A^{\prime} \rightarrow B \rightarrow C$ $\rightarrow$ に該当する.

$$
\begin{gathered}
g^{p}=\forall d \\
\left(\mathrm{v}_{\mathrm{r}}^{\mathrm{p}} \notin \mathrm{v}^{\mathrm{o}}, \mathrm{d}_{\mathrm{r}}^{\mathrm{p}} \notin \mathrm{d}^{\mathrm{o}}\right)
\end{gathered}
$$

\section{g）推論不能状態からの復帰}

式(26)は, 式(22), (25)に示寸ランダムウォーク状態の ときに，既知情報に含まれている地点情報 $v_{r}^{p}$ が偶然案 内される場合である. 運転者は，このとき予定経路に復 帰できる可能性が高くなる.

$$
\begin{gathered}
g_{r}^{p}=d_{r}^{p} \\
\left(\begin{array}{l}
v_{r}^{p} \in \mathrm{v}^{0}, \\
\mathbf{v}_{\mathrm{r}-1}^{\mathrm{p}} \notin \mathrm{v}^{\mathrm{o}}, \mathrm{d}_{\mathrm{r}}^{\mathrm{p}} \notin \mathrm{d}^{\mathrm{o}}
\end{array}\right)
\end{gathered}
$$

\section{（4）代替に関する演算則}

本節では，予定経路をはずれて走行中であることを案 内により認識した運転者の推論に限定した「方向演算」 を考える.これは図-4のGおよび式(21)に該当する.こ の場合の代替推論は，第 2 章で述べた非単調推論にあた り，推論結果の最適性を保証するものではない.

図-7の例では，運転者は予定経路を走行していると 思っているが，実際には予定経路外を走行している.こ のとき, 案内標識によって予定経路(細実線)の中継地点 である(5)の案内が出現し，その方向が既知情報の方向と 
違うことから，予定経路外を走行していることを認識す る場合である.

この場合には，運転者は左折を選択して(5)に至るこ とができるが，この運転者が予定経路に復帰寸るために (5)と思われる地点において選択すべき方向が問題となる.

本研究では，これらを推論值 $\{\theta\}$ として求める演算体 系を考察する.

なお，以下の演算体系の適用条件は，次の 2 点である. (1)予定経路をはずれたことを案内により認識した運転者 を対象とする.

(2)予定経路上の既知情報である経由地名または経由路線 番号の案内があり, その経由地と思われる地点を何らか の方法（交差点の大きさ・幅, 最初に現れた交差点, 距 離と方向などによるおおまか推論）で特定する.なお， 正確な地点に到達できているかどうかの保証は必要とし ない.

ところで, 経路における位置にもとづく進路決定は, 格子状 (grid map) の認知地図を基本としている ${ }^{14)}$ のが一 般的とされている。 したがって，格子状に近い形状の ネットワークの方が複雑な形状のネットワークよりも本 推論の精度は高くなる.

a) 記号

演算体系には，方位および方向転換の向きを要素とし て用いる.

(1)方位

方位は, 東西南北の 4 種類とする. 本研究では, 予 定経路の最初の出発方向を $N$ とし, $E, S, W$ は $N$ 対す る相対方位として取り扱う。

(2)方向転換の向き

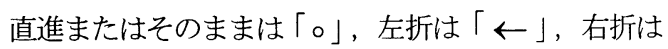

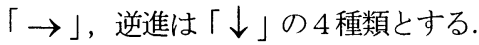

b) 記号の数値化

本研究では格子型の道路網を想定しているので, 演 算を容易にするため，上記の記号を数值化することを試 みる。

反時計回り 90 度単位の方向転換が， $0, \pi / 2, \pi, 3 \pi / 2$ であるときの方向は, ド・モアブルの定理より, 次式で 表現できる.

$$
e^{i \cdot 0}=1, e^{i \cdot \frac{\pi}{2}}=i, e^{i \cdot \pi}=-1, e^{i \cdot \frac{3 \pi}{2}}=-i
$$

ここに, $e$ は自然対数の底であり, $i$ は虚数単位で ある

したがって，方位に関しては，

$$
N=\{1\}, W=\{i\}, S=\{-1\}, E=\{-i\}
$$

同様に, 方向転換の向きは,

直進またはそのまま「。」= 1 , 左折「 $\leftarrow 」=i$, 逆進 $\downarrow \downarrow=-1$, 右折 $\ulcorner\rightarrow\rfloor=-i$
とする.

\section{c）記号の合成則と代数演算則}

いくつかの方向転換を組み合わせた後の方向，すなわ ち進行方向の合成則および方位と方向転換の合成則，そ して，それらの代数演算則について以下に例示する.

進行方向相互の合成に関しては,

$$
\begin{gathered}
\{\circ \leftarrow\}=1 \times i=i=\{\leftarrow\} \\
\{\rightarrow \leftarrow\}=(-i) \times i=1=\{0\} \\
\{\rightarrow \downarrow\}=(-i) \times(-1)=i=\{\leftarrow\}
\end{gathered}
$$

また，左折と左折，右折と右折など，同方向転換の合 成に関しては,

$$
\begin{gathered}
\{\leftarrow \leftarrow\}=i \times i=-1=\{\downarrow\} \\
\{\downarrow \downarrow\}=(-1) \times(-1)=1=\{0\}
\end{gathered}
$$

式(30)〜(32)に関しては，交換則が成り立つ.

方位と方向転換の合成に関しては,

$$
\begin{aligned}
& N\{\rightarrow\}=\{1\} \times(-i)=\{-i\}=E \\
& S\{\rightarrow\}=\{-1\} \times(-i)=\{i\}=W
\end{aligned}
$$

\section{d) 計算例}

ここで，以上の演算則を図一のケースへ適用してみる. まず，細実線で示す予定経路にしたがって(5)に到達し， 。 (5)で進行方向を決定するまでの動きと, その結果進行す る方位に関する演算式を表すと，次のようになる。

$$
N\{0 \rightarrow \leftarrow\}=\{1\} \times 1 \times(-i) \times i=\{1\}
$$

式(37)は, 出発点(7)から $N$ の方位に向かい, 右折, 左 折と方向を 2 回転換すると, 結局は元の方位 $N$ に向かっ て進むことになることを表している.

次に，予定経路外の経路である太破線を走行中に，(5) に到る案内を既知情報の方向と異なる方向に案内された 場合を考える.

(5)に到着した後の進行方向を $\{\theta\}$ とすれば，一連の動 きと(5)到着以降の進行方向は, 次式で表される.

$$
\begin{aligned}
N\{0 \rightarrow \leftarrow \leftarrow \theta\} & =\{1\} \times(-i) \times i \times i \times \theta \\
& =\{i\} \times \theta
\end{aligned}
$$

これが，予定経路と同じ方位にならなければならない．

つまり，式(37)と式(38)の値は等しく，

$$
\{1\}=\{i\} \times \theta
$$

よって,

$$
\theta=\{1\} /\{i\}=1 / i=-i
$$

すなわち，「(5)と思われる分岐点を右折する」と推論す ることとなる.

このようにして，運転者の進行方向を演算すること ができる．ただし，式(21)に示寸ように，走行中の方向 


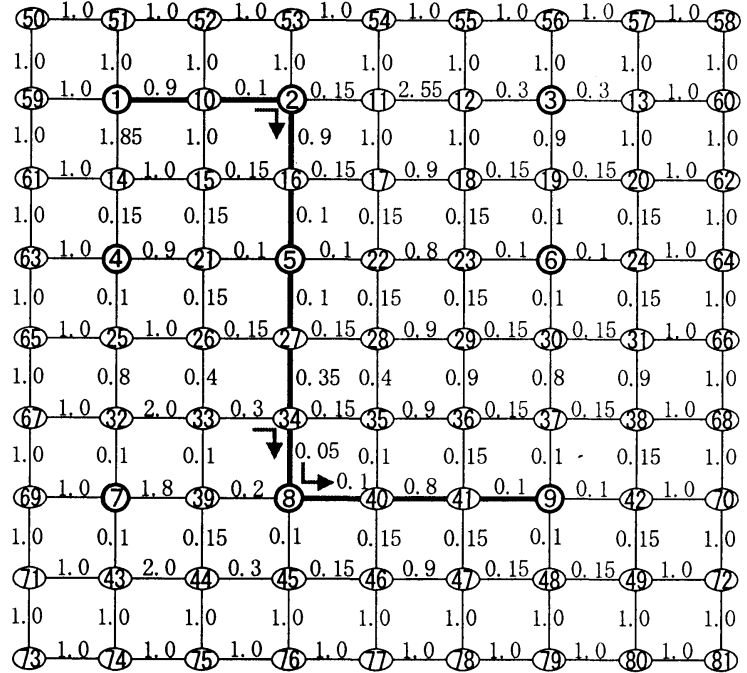

図-8 例題の道路網

転換数を制約条件とするので，方向転換数が多すぎる場 合には,この推論は成立しない.

ところで, ここで示したような数理的な演算が，その まま運転者の頭の中で行われているとは考えられない. しかし一方で, メンタルモデルの立場に立てば, 一定の 条件の下でこうした代替演算が可能である以上，運転者 がこれと類似の機能を持つ何らかの推論を行いうると考 えられる.

\section{4．迷走に対する推論の影響}

本章では，これまでに述べてきた運転者の推論が，迷 走の抑止にどのように影響しているかを明らかにするた めに, モデル道路網を対象として, 推論機能の有無によ る走行状況の比較を行うものである.

\section{(1) 道路網}

計算例に用いる道路網は, 図-8 に示す往復 288 リン ク, 81 ノードの道路網である. 丸枠ゴシック体数字は ノードを表し, 他の数字はノード間の距離を表す.

分析対象とするODの出発ノードを(1)，目的ノード を(9)とし，(1)から(9)に至る最短経路は，太線で示す(1) $\rightarrow$ (10) $\rightarrow$ (2) $\rightarrow$ (16) $\rightarrow(5)-(27)-(34) \rightarrow(8)-(40)-(41) \rightarrow(9)$ と才る. その 経路長は 3.5 である．また，通過すべき交差点およびリ ンクの数は 9 箇所であり, 方向転換箇所は，(2)および8) の 2 箇所である.

最短経路上で案内標識を設置する位置は, リンク (10)

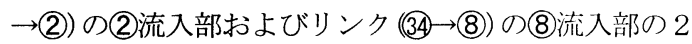
箇所であり，その内容は，『右折すると「8)（または

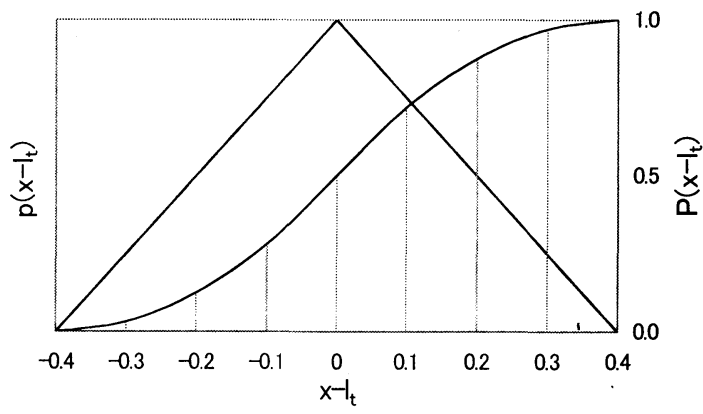

図-9 方向転換ノード選択の確率分布

「(9)）に至る』および『左折すると「(9)」に至る』と する.

最短経路以外のリンクに関しては, リンク(3)-(34)の (34) 流入部の 1 箇所であり, その内容は, 『右折すると

「8」に至る』とする．この案内は，最短経路以外の経 路を走行中の運転者にそのことを自覚させ，最短経路に 復帰するための代替推論を可能にする.

例題のODは 1 組であるが，現実の道路網では多数の ODが存在し, それらに対する案内誘導も混在している. そのとき，ある経路の案内が他の経路への案内を兼ねた り，または予定経路へ復帰させたりする効果をもつ場合 がある．後者の効果を検証するために，本例では最短経 路以外のリンクにも案内することとした.

\section{（2） 既知情報}

案内情報に対して直接対応する既知情報は，地点情報 に関して,

$$
\operatorname{via}(2),(8),(9))
$$

方向情報に関しては,

$$
\operatorname{direct}(\text { 右, 左) }
$$

結合情報に関しては,

$$
\text { concat(2).右, (8).左, (9) }
$$

案内情報に対応しない既知情報としては，中継地点 間の距離があり,

$$
\text { length }\left(l_{1,2}, l_{2,8}, l_{8,9}\right)
$$

とする

\section{（3）方向転換位置の同定}

式(20)で用いた各運転者の方向転換位置同定に関する 分布関数 $F\left(l_{c}, x_{r}\right)$ の確率変数を, 走行距離 $x$ と各リン クの認知的距離 $l_{c}$ との差と仮定する.

図-5，6 で示した考え方を推論モデルに適用するには， $g\left(l_{c}\right)$ と $f\left(x-l_{c}\right)$ の命成分布を決定す心゙きであるが,現 段階では, $g\left(l_{c}\right)$ および $f\left(x-l_{c}\right)$ ともに具体的な分布型 
が不明であるので，本例では図-9 に示すように，認知 的距離のピーク值（平均值）は各リンクの真の距離 $l, に$ 等しいと仮定し, 確率変数を $x-l$, として, 方向転換位 置同定の確率密度関数 $p\left(x-l_{t}\right)$ を 3 角形分布型で仮定 した上で，その分布関数 $P\left(x-l_{t}\right)$ を求めた.

なお，図-9 は現実の走行において検証したものでは ない. しかし，走行シミュレータを用いた仮想の進路選 択実験では，真の距離近くの分岐点をピークとした分布 が得られており ${ }^{15)}$ ，現時点では，図-9 の仮定は妥当と 考える.

\section{(4) 評価指標}

迷走の程度を表す評価指標としては，最短距離（予定 走行経路）で到達した台数，e\%到達距歌，および著者 らが定義した次式の到達迷走度 ${ }^{8)}$ を用いる.

$$
\mathrm{H}(\Xi)=\sum_{\mathrm{e}}\left(\frac{\mathrm{t}_{\mathrm{e}}(\Xi)}{\mathrm{t}_{\mathrm{o}}(\Xi)}-1\right)
$$

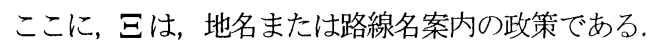
また $\mathrm{t}_{\mathrm{e}}(\Xi)$ はODの最短到達距離であり, $\mathrm{t}_{0}(\Xi)$ は榇計 で $\mathrm{e} \%$ の運転者が到達する距離である.

到達迷走度は，予定経路以外を走行した運転者の走 行距離の度合いを考慮しているので, 目的地に到達寸る までに走行する距離の長い運転者が多い程，值が大きく なる. 全運転者が最短距離で到達する場合，つまり，予 定経路以外を走行する運転者が皆無の場合には, 到達迷 走度は 0 となる.

なお, 試行回数（車両台数）は 100 万回とし, 到達 迷走度の算定には, そのうちの, 目的地一の到達順に早 い方から 90\%を対象とした。

\section{（5）推論機能の組み合わせケース}

推論機能の計算例は, 案内がない場合が 2 ケース, 案 内がある場合が 3 ケースの計5ケースとする.

ケース 1 : 推論機能がなく, 案内情報も与えられていな い.

ケース 2 : 推論機能として, 予定分岐点間の認知的距離 にもとづく方向推論機能のみがあり, 案内情 報はない。

ケース 3 : ケース 1 に案内情報が加えられている.

ケース 4: ケース 2 に案内情報が加えられている.

ケース 5 : ケース 4 に代替推論機能が加えられている. ただし，方向転換数が $R$ を超える場合は，次 に遭遇する分岐点ではランダムウォークとな る. また，方向転換数の上限值 $R$ には，直接 短期記憶容量の標淮項目数 る. なお，本例題では第 3 章(3)の「経由地 と思われる地点（例えば，図-7では地点(5)

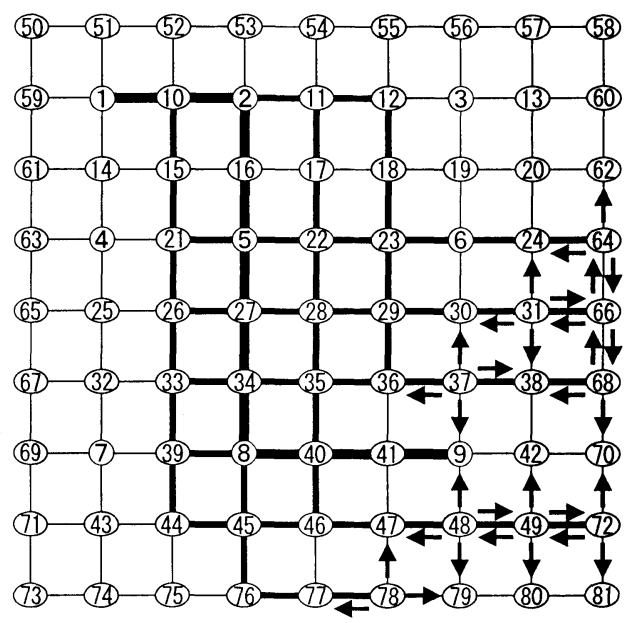

図-10 推論不能状態になるまでの走行経路(ケース 2)

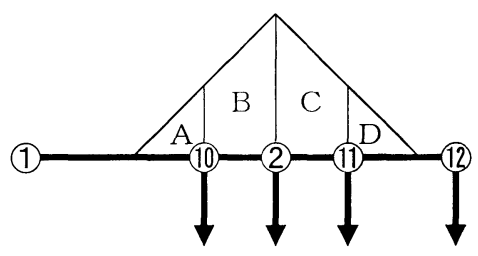

図-11 方向情報による方向転換

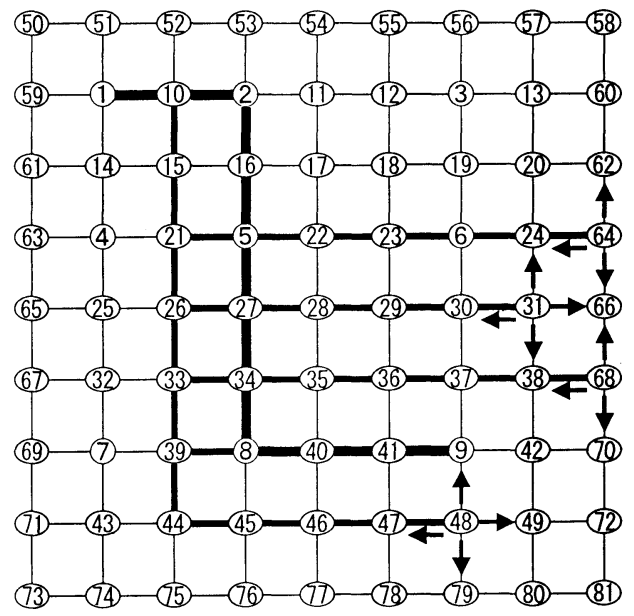

図-12 推論不能状態になるまでの走行経路(ケース 5)

に該当する.)」は，案内にしたがって進入し たリンクでの次の交差点とした. 
表-1 計算結果

\begin{tabular}{|c|c|c|c|c|c|c|}
\hline \multicolumn{2}{|c|}{ 計算ケース } & 1 & 2 & 3 & 4 & 5 \\
\hline \multicolumn{2}{|c|}{ 案内 } & 無し & 無し & 有り & 有り & 有り \\
\hline \multicolumn{2}{|c|}{ 認知距離 } & 無し & 有り & 無し & 有り & 有り \\
\hline \multicolumn{2}{|c|}{ 代替推論 } & 無し & 無し & 無し & 無し & 有り \\
\hline \multicolumn{2}{|c|}{ 使用情報 } & ランダム & 方向 & ランダム & $\begin{array}{l}\text { 方向 } \\
\text { 結合 } \\
\text { 地点 }\end{array}$ & $\begin{array}{l}\text { 方向 } \\
\text { 結合 } \\
\text { 地点 }\end{array}$ \\
\hline \multicolumn{2}{|c|}{ 最短到達台数 196} & 0.0004 & 11.1 & 0.006 & 44.3 & 44.3 \\
\hline \multicolumn{2}{|c|}{ 最短到達距離 } & 3.5 & 3.5 & 3.5 & 3.5 & 3.5 \\
\hline \multicolumn{2}{|c|}{$90 \%$ 到達迷走度 } & 271.5 & 67.1 & 248.7 & 45.8 & 16.6 \\
\hline \multirow{2}{*}{ e } & $10 \%$ & 26.3 & 3.5 & 22.85 & 3.5 & 3.5 \\
\hline & $20 \%$ & 41.15 & 4.2 & 36.75 & 3.5 & 3.5 \\
\hline$\%$ & $30 \%$ & 56.0 & 7.15 & 50.35 & 3.5 & 3.5 \\
\hline \multirow{2}{*}{ 到. } & $40 \%$ & 72.0 & 10.75 & 65.55 & 3.5 & 3.5 \\
\hline & $50 \%$ & 90.85 & 15.75 & 83.15 & 6.35 & 3.95 \\
\hline 達 & $60 \%$ & 113.6 & 23.85 & 104.35 & 13.4 & 3.95 \\
\hline \multirow{3}{*}{$\begin{array}{l}\text { 距 } \\
\text { 離 }\end{array}$} & $70 \%$ & 143.0 & 37.9 & 131.85 & 25.35 & 6.05 \\
\hline & $80 \%$ & 183.9 & 61.25 & 170.3 & 46.8 & 16.1 \\
\hline & $90 \%$ & 254.9 & 102.15 & 236.7 & 85.9 & 45.55 \\
\hline
\end{tabular}

\section{(6) 計算結果}

各ケースの計算結果は，表-1 および図-10〜14 に示す. 推論が機能しないケースは, 1 および3であり，機能 するケースは，2，4および5である.

\section{a）方向情報と認知的距離にもとづく方向転換}

方向情報と認知的距離にもとづく推論が機能する ケース 2 において, 推論不能状態になるまでの経路を 図-10 に示す.太線は, そのときの走行経路であり，そ の内の最太線は予定走行経路である．案内がないにもか かわらず, 推論の効果として, 走行する主要なリンクが 絞り込まれているのがわかる. なお，矢印が各方向に出 ているノードは, 推論不能になるノードであり，すべて の運転者がランダムに進路を取り始めることを示してい る.

ケース 2 において，予定経路の最初の方向転換は， 「分岐点(2)を右折」である. しかし，その直前の分岐点 (10)を右折する運転者が，0.28（図-11 の面積A）の確率 で発生している. また, 予定分岐点(2)を右折する運転者 は, 0.22 (面積B）の確率で発生し, 直後の分岐点(11) よびその後の分岐点(12)゙の右折車の発生確率は, 0.30

（面積C）および0.20（面積D）となる.

なお, 最短到達台数は, 図-9 の $\mathrm{x}$ 軸分布幅の設定に より変化し, 分布幅が狭くなると, 予定分岐点(2)を右折 する運転者数は増加する.

案内が設置された場合であるケース 5 において，推論 不能状態になるまでの経路を図-12 に示す．この場合に

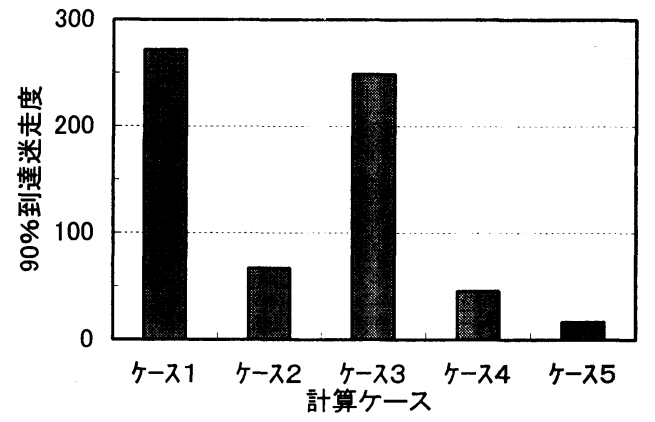

図-13 90\%到達迷走度

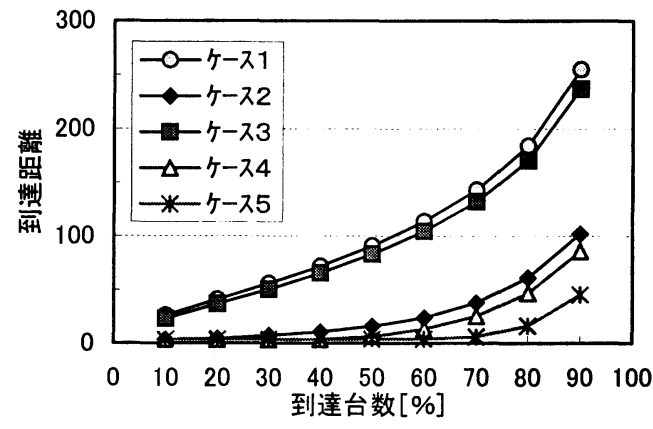

図-14 到達台数と到達距離の関係

は, リンク (10)ー(2)) に案内が設置されているので, 図11 の面積CおよびDの分も予定分岐点(2)を右折するこ ととなり，右折分岐点の発生確率は分岐点(10)゙゙ 0.28 , 分岐点(2)では 0.72 となる. ケース 4 でも同様である.

\section{b) 最短到達台数}

まず，案内がない場合について考察する.

最短経路上の通過分岐点数は 9 であるので, 表-1 に 示すように，ケース 1 での最短到達台数は， $1 / 4^{9} \fallingdotseq$ $0.0004 \%$ となる. 現実には, 案内が皆無でも，ほとんど すべての運転者が予定経路からはずれて迷走するという ことは考えにくく, ケース 1 の計算結果は, 現実的な值 ではない.

ケース 2 では，運転者は，方向転換で描く走行形状と 認知的距離にもとづいて進路を決定しているので, 最短 距離で到達する運転者は，ケース 1 よりも多くなり， 約 $11 \%$ となっている. ケース 2 の計算結果は, ケース 1よりも現実に近づいていると思われる.

次に，案内がある場合について考察する.

ケース 3 では, 最短経路上に 2 箘所の案内があるので, 最短到達台数は， $1 / 4^{7} \fallingdotseq 0.006 \%$ となるが，ケース 1 と 同様に，ほとんどの運転者が最短経路では到達していな いといえる.

ケース 4 では，案内がないときには，ケース 2 と同じ く，方向情報にもとづき推論し，案内があるときには， 
結合または代理結合情報，および地点情報にもとづき推 論する. この場合の最短距離での到達台数は, ケース 2 より増え, 約 $44 \%$ となっている.

ケース 5 では, さらに代替推論も機能しているが，代 替推論は予定経路以外の走行を含んでいるので，最短到 達台数の増加には貢献しない. よって, 最短到達台数は, ケース 4 と同数となる.

\section{c） $90 \%$ 到達迷走度および e \%到達距離}

表-1 および図-13に示すように，90\%到達迷走度が大 きいのは，ケース 1 および3であり，迷走状態が顕著に 現れている. 次いで, ケース $2,4,5$ の順に小さくなっ ている. また，到達台数と到達距離の関係を図-14 に示 す. 長い距離で到達する運転者が多いほど, 到達迷走度 は大きくなるという関係があり，図-14 でもケース 1 お よび 3 の到達距離は, 他のケースより大きな值となって いる.

ケース 1 と 2 の違いは, 認知的距離にもとづいた方 向推論の効果であり, ケース 2 と 4 の違いは, 案内標識 の誘導効果である.

ケース 4 と 5 は, ケース 3 よりも到達迷走度が小さ くなっている. ケース $3,4,5$ は，いずれも案内があり， その内容も同一であるので, この差は推論（特に, 認知 的距離にもとづいた方向推論) の効果である.

また，予定経路以外に設置されているリンク (33)-(34)

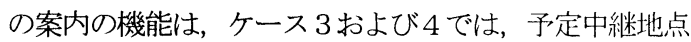
8にに復帰させるだけであるが，ケース 5 では，代替推論 である式(21)の条件を満足する場合には，その後の進む べき方向を「左折」と推論することができる. よって, ケース 4 と 5 の到達迷走度の違いは, 代替推論による効 果である.

なお，ケース 4 および 5 においては，方向転換の案内 が設置してあるリンクの直前のリンクで方向転㨦して予 定経路以外のリンクを走行する運転者が発生している.

これは，図-9，11 に示すように，真の距離より短い走 行距離で, 方向転換してしまう運転者が存在しているた めに起こる現象である.

したがって，迷走車を減少させるには，方向転換す ベき交差点の流入部だけではなく，その前のリンクで, まだ方向転換するときではなく「直進である」という案 内を設置すべきことが理解できる．これは，現実の道路 での案内板に見られる直進案内の有効性を裏付けるもの と考えられる.

\section{5. あとがき}

本研究は, 予定経路を走行寸るときのリンク選択にお ける進路決定推論に関して, 情報処理的取り組みの立場
から,メンタルモデルを構築することを目的として，数 理モデルの提案および定式化を行い，各推論の特性を示 したものである．本論文で明らかになったことと今後の 課題について以下に述べる.

\section{(1) 推論システムの機構}

情報の種別は，出発前の情報を既知情報とし，走行 中に標識などから得られた情報を獲得情報とした．それ らの構成要素として, 地点情報, 方向情報および距離情 報を考え，それらにもとづき，結合情報および代理結合 情報を定義した．なお，情報の構造は，時間・位置的な 順序を表す順序集合とし，距離情報は認知的歪みを持つ ものとした:

これらの情報を入力とした推論の機能は，獲得情報 がない場合には，認知的距離と既知の方向情報にもとづ き走行形状を認識し，方向転換箇所を推論するものとし た。 また，獲得情報がある場合には，結合情報，代理結 合情報，地点情報のいずれかにより，方向転換箇所を推 論するものとした.

さらに，運転者が予定経路外を走行していることを 認識した場合には，条件が満足すれば，代替推論を行う ものとした.

\section{(2) 推論の効果}

例題の結果から，案内が全くない場合でも，認知的 距離にもとづいた方向推論により, ランダムウォークの 確率值よりも非常に多数の運転者が予定経路上を走行す ることが判明した. また，有効な案内により比較推論が 機能し, より多数の運転者が予定経路上を走行すること になる.ささらに，予定経路外走行を認識した運転者が代 替推論により争定経路に復帰することも示すことができ た.

これらの結果は計算条件（道路網，OD数, 経路, 標識の設置箇所・内容）によって変化すると思われるが, 各評価項目値の大小関係は变化せず，予定経路以外の走 行リンク絞り込みの順芧も変わらず, 定性的一般性はあ ると考える.

また，推論機能が働く結果，予定経路外の主要な経 路が判明する. それらのリンクと予定経路上のリンクが 案内誘導箇所の候補となり, 有効でない案内箇所の候補 が排除でき，無䭾な標識の設㯰を防止できることになる. また，このことにより最適化計算時の組み合わせ数が大 幅に減少するので, 案内誘導の条件付き最適化問題の求 解困難性が改善される.

本研究により, 推論が案内情報の不完全さを補いつ つ，運転者を目的地に導く効果をもつことが判明した. その中でも認知的距離にもとづく方向推論の機能の効果 は大きく，推論の中心的役割を果たすのではないかと考 
えられる。

以上より，本モデルを従来の案内誘導システムに組 み込み，それを再構築することは有意義なことと思われ る.

\section{(3) 今後の課題}

本論文では，論理性のある推論モデルをシステム化 できた。しかし，認知的歪みの分布特性は未解明であり， 計算例では認知的距離の歪みを三角形分布で仮定したの で，定量的には必ずしも十分ではない.

このような認知的歪みを定量化することは容易では ないが，今後本モデルをより現実的なモデルとするため には，認知的歪みを原因とした認知的距離の確率分布の 特性および定常性を検証し，適切な分布パラメータを求 めることは重要と考えられる. このため, 走行シミュ レータによる室内実験を現在実施中であり，代替推論の 検証を含めた実走行実験も計画中である.

また，本研究により，案内設置箇所候補の絞り込み の可能性を示すことができたが，さらに案内名とその案 内方向候補の絞り込みの原理を解明する必要がある。こ の点については，案内誘導システムの最適化問題八適用 する場合に効果を発揮すると思われるので, 今後の課題 としたい.

\section{参考文献}

1）満田喬 : 案内標識の表示手法に関する一考察，土木研究所 資料第 2072 号, pp. 27-71，1984.

2) 栗本典彦: 案内標識の設置効果に関する評価手法, 交通工 学, Vol. 14 /No.2, pp. 3-9, 1979.

3）若林拓史 : サクセスツリーとファジィ理論を用いた道路案 内標識の経路誘導効果評価モデル，第 10 回交通工学研究 発表会論文集, pp. 121-124， 1990.

4）若林拓史 : サクセスツリー法による道路案内標識の経路誘
導効果評価モデルの適用，第 11 回交通工学研究発表会論 文集，pp. 117-120，1991。

5) 外井哲志 : 道路網におうる地名案内標識の最適配置に関す る研究, 第 12 回交通工学研究発表会論文集, pp. 5356, 1992.

6）野村哲郎，外井哲志，清田勝 : 都市間道路網における方面 案内標識の最適配置に関寸る基礎的研究, 土木計画学研 究・論文集, No. 13, pp. 877-884, 1996.

7) 野村哲郎, 外井哲志, 清田勝 : 道路網における案内標識の 最適配置に関寸る研究, 土木学会西部支部研究発表会, pp. 652-653, 1997.

8) 野村哲郎, 外井哲志, 清田勝 : 経路復元誘導機能を考慮し た道路案内標識システムに関する研究，土木学会論文集， No. $625 /$ IV-44, pp. 125-134， 1999.

9）朝倉康夫, 羽藤英二：交通ネットワーク上の経路選択行 動:観測と理論，土木学会論文集，No.660/IV-49，pp. 3-13, 2000.

10) 安西祐一郎, 市川伸一，外山敬介，川人光男，橋田浩一： 脳と心のモデル，認知科学第2巻, 岩波書店, pp. 1136, 1994

11) 中島秀之, 高野陽太郎, 伊藤正雄 : 思考, 認知科学第 8 巻, 岩波書店, pp. 109-149，1994.

12) 佐伯 胖, 戸田正直: 認知科学の方法, 認知科学選書第 10 巻，東京大学出版会，pp. 129-172，1997.

13）長山泰久, 矢守一彦 : 空間移動の心理学, 福村出版, pp. 104-117, 1992.

14）若林芳樹：認知地図の空間分析，地人書房，pp. 81124,1999

15) 今田邦明, 辰巳 浩, 外井哲志, 野村哲郎 : 認知距離にも とづいた交差点の進路選択特性に関する研究，土木学会西 部支部研究発表会, pp. B260- B261，2001.

(2001. 2. 13 受付)

\title{
INFERENCE MODEL OF COURSE DIRECTION ON ROAD NETWORK
}

\author{
Tetsuroh NOMURA, Satoshi TOI and Masaru KIYOTA
}

Traffic guide signs are essential information source for drivers who are unfamiliar with the geography to reach their destinations. But the contents of the traffic guide signs are not complete because all drivers' destinations are not shown. Thus it is important to establish an inference model of the course direction on driving road network.

This paper proposes a mental model method for the inference with the shape of concatenated links and cognitive length. This model evaluates the effect of the inferences by simulating. The model assumption and the model building process are discussed and numerical analyses are executed for a road network. 